\section{Seven go environmental}

\section{Paris}

THE planned coincidence of France's bicentenary celebrations with the fifteenth annual summit of the seven most industrialized nations ended with a spectacular weekend, but an unsurprising summit. Under President Francois Mitterrand's patronage, many expected the seven (G7) to announce significant resolutions on the environment and on north-south relations. But no new measures were agreed.

$\mathrm{L}_{h}$ der pressure lobbying from four of the world's poorest nations, Mitterrand opened the summit with a plea for a north-south summit. But this was politely put aside, with Britain and the United States the least enthusiastic. Instead, the accent was firmly placed on east-west relations, with President Bush fresh from his visit to Poland and Hungary last week.

The biggest surprise of the summit was a letter from Mikhail Gorbachev to President Mitterrand, delivered on Saturday. The letter expressed a desire of the Soviet Union to take a full share in international political and economic issues, in effect a request to join the next summit to be held in the United States in 1990. The seven were unanimous in agreeing that the time was not yet ripe.

On the environment, the seven reinforced the 1987 Montreal agreement to cut production of chlorofluorocarbons by the year 2000 , but declined to introduce any new initiatives on global environmental issues. Deforestation was identified with problems of Third-World debt, for which "greater realism" on the part of the commercial banks and proper economic strategies for debtor nations were seen as remedies. The problems of flooding in Bangladesh and desertification in Africa were singled out as urgent priorities. The seven called for a conference on Bangladesh before the end of the year, possibly sponsored by the World Bank.

The summit was inevitably swamped by the French festivities and the most piquant political events took place outside the meetings. While the seven richest nations

\section{CARBON DIOXIDE EMISSIONS}

met in a luxurious suite at the top of the brand-new Arche de la Defence building, "The other ecomomic summit" of researchers and economists from some of the poorest nations united at the down-atheel Mutualité assembly rooms.

The high point of the weekend was an extravagant parade down the ChampsElysees. But insiead of break-dancing
Chinese students, as originally planned, the parade was led by a solemn procession of young Chinese in mourning pushing bicycles and ringing bells to the beat of drums. And two leaders of the Chinese student movement came out of hiding to inaugurate a replica of the statue of liberty demolished by tanks in Tiananmen square. At the summit, the seven nations avoided sanctions against China, calling for political and economic reforms and greater openness.
Peter Coles

\title{
Japan seen in good light
}

\section{Tokyo}

THE United States, the Soviet Union and China are pumping more carbon dioxide into the atmosphere than any other nations. By the year 2030, their emissions will have doubled or tripled and output from developing nations will also contribute a large proportion of worldwide emissions. Japan's carbon dioxide output, on the other hand, will show only modest growth and will constitute a tiny fraction of world output by 2030 .

These are the main results of an analysis of worldwide energy consumption released last month by a study group of Japan's Ministry of International Trade and Industry (MITI). The group concludes that the United States, the Soviet Union and Chinet Union stricter controls of car- China

bon dioxide emissions. Developing countries This view is shared by other Japanese government agencies and Figures in parenthesis indicate percentage of world share. China is included gives an indication of as a 'developing country'.

the stance Japan is likely to take in international discussions of the problem of global warming caused by build-up of carbon dioxide in the atmosphere.

The study group on long-term global energy problems, an advisory group composed of academics, media representatives and members of private industry, examined worldwide energy consumption and carbon-dioxide emissions in 1986 and made projections for 2030 .

The United States is currently the world's leading source of carbon dioxide, accounting for 23 per cent of emissions, with the Soviet Union a close second (18 per cent) and China third (11 per cent). Developing nations (including China) also contribute a large proportion ( 26 per cent) and their emissions are expected to show a dramatic four-fold rise by 2030 , accounting for about a third of a total world output of about 18,000 million tons (on a carbon weight basis) by that time.

\section{IMAGE UNAVAILABLE FOR COPYRIGHT REASONS}

The heads of government of the honoured 'G7' face the press. 'Extra' man (far left) is Jacques Delors of the European Community. (AP). 